\title{
WETTING AND WICKING OF HOSPITAL PROTECTIVE TEXTILES*
}

Anita Tarbuk**, Sandra Flinčec Grgac, Tihana Dekanić

University of Zagreb Faculty of Textile Technology, Department of Textile Chemistry and Ecology, Zagreb, Croatia

Moisture management, as one of the key performance criteria in terms of fabric comfort, specifically on cotton fabrics intended for use in a hospital environment, was investigated in this paper. For this purpose, commercial cotton fabrics for surgical gowns and hospital linen were used, as well as standard cotton fabrics treated with various cationic antimicrobial protection agents. The antimicrobial properties were achieved by cationization with 3-chloro-2-hydroxypropyl-trimethyl ammonium chloride, or reactive polyammonium compounds Rewin OS; and by treatment with quaternary ammonium compounds (QACs), N-cetylpyridinium chloride (N-CPC) and cetylpyridinium bromide (CPB), which act as surfactants and antiseptics. Standard cotton fabric has excellent hydrophilicity, fast absorption and spreading, large spreading area and good one-way transport. It is characterized as Moisture management fabric. Hospital white linen fabric has a water repellent finish; however, it is breathable and can be characterized as a Water penetration fabric. Hospital green fabric for gowns and instrument covers, due to dyestuff blocking the active groups have smaller absorption, and is characterized as Fast absorbing and quick drying fabric. Cotton fabrics have negative zeta potential. Cationization change surface charge, as well as antimicrobial activity. In MMT both cationized cotton fabrics are characterized as Fast absorbing and quick drying fabric, as they have fast wetting, absorption and spreading, a large spreading area, but poor one-way transport. For the QAC treated fabrics this effect is more enhanced. However, these fabrics have excellent antimicrobial activity even after desorption. Based on the results of wetting and wicking, zeta potential and antimicrobial activity, CPB treatment is proposed for the processing of cotton fabrics.
(ORIGINAL SCIENTIFIC PAPER) UDC 677.017:615.478.2

Keywords: hospital textile, cationization antimicrobial properties, moisture management, zeta potential, wetting and wicking.

\section{Introduction}

Among numerous requirements on textiles that are aimed for use in hospital environment, some are more important than the others, e.g., antimicrobial properties, minimum fabric damage and minimal amount of textile dust generated after textile care processes, as well as comfort, especially for gowns and linen. The antimicrobial treatment leads to prevention or reduction of microorganism growth on the fabric, preventing the infection in the hospital environment and during care [1-3]. Majority of commercial products with antimicrobial effect, mostly based on quaternary ammonium compounds (QACs). QACs, especially the ones having chain length of 12-18 carbon atoms, are widely used as antiseptics and disinfectants, fabric softeners, as well as for clinical purposes, hard-surface cleaning and deodorization. Nowadays are gaining more importance due to its functionality and environmental benefits. QACs have ability to inactivate the bacterial cells, whilst the quaternary ammonium group remains intact and retains its antimicrobial ability as long as the compound is attached to textiles [3-5].

However, for high levels of comfort, a fabric must allow air, and especially the moisture (water vapor) generated by the exudation of perspiration from the skin during physical activity, to pass through the fabric. This maintains the wearer of the garment in warm, dry conditions with high levels of thermophysical and thermophysiological comfort [6-11]. In the case of beddings, it has to be fast drying fabric with the ability to take away liquid by capillary force. The moisture management is one of the key performance criteria regarding the fabric comfort.

Moisture may be transferred through a fabric in liquid or in vapor form. As water vapor, moisture can be transferred by diffusion, absorption, transmission and desorption through fabric layers; as adsorption and migration along the fiber surface, and as transmission by forced convection; whilst the liquid moisture transfer through a

*The paper was presented at 13th Symposium with international participation "NOVEL TECHNOLOGIES

AND ECONOMIC DEVELOPMENT" as a plenary lecture, Faculty of Technology in Leskovac,

18-19 October, 2019.

** Author address: dr Anita Tarbuk, University of Zagreb Faculty of Textile Technology, Department of

Textile Chemistry and Ecology, Prilaz baruna Filipovića 28a, HR-10000 Zagreb, Croatia

E-mail: anita.tarbuk@ttf.hr

The manuscript received: September, 19, 2019. 
fabric consists of two processes - wetting and wicking [6-14]. Wetting is a process when the fiber-air interface is replaced with a fiber-liquid interface. Wicking process follows wetting; it starts when the liquid enters into the capillary formed between two fibers or yarns by the capillary forces [12,13]. Spreading and absorption of the liquid over the surface of the fabric depends on the interaction between the forces of cohesion (within the liquid) and the forces of adhesion (between the fibers and the liquid).

The adsorption and wettability of textile material have significant influence on finished textiles. These phenomena occur at solid-liquid interface, like textile material and water solution. In general, specific adsorption of ions or dissociation of the surface groups in aqueous solution results with their surface charge. It depends on their molecular and supramolecular structure, swelling capacity, ionogenity, structure and concentration of adsorbate [13, 15-18]. Any change in the number of functional groups, e.g. by blocking in dyeing and finishing processes, and their dissociation affect the distribution of surface charge, surface free energy as well as the thickness and distribution of the electric double layer results in different fabric interface phenomena [15-23].

When a drop of liquid sets on solid surface, it creates a contact angle. The wettability and surface free energy of a textile can be characterized by the examination of the contact angles that different liquids form on it [13, 15, 19]. However, textiles are heterogeneous, porous and mostly hydrophilic material, and for such surfaces it is sometimes impossible to determine contact angle [13]. Therefore, the Chibowski thin-layer wicking method for the textile surface free energy components determination is more appropriate $[13,24,25]$.

Since there is heterogeneity of the test methods and of the time scales for wetting, wicking and absorption determination, among other difficulties in the interpretation of the results, the aim of this paper was to determine the moisture management, as one of the key performance criteria regarding the fabric comfort on cotton fabrics used in the hospital environment and to compare different methods. The antimicrobial activity of the tested hospital textiles was also determined.

\section{Experimental}

\section{Material}

In this research the commercial cotton fabrics for surgical gowns, instrument covers and hospital linen, as well as standard cotton fabric of next characteristics were used: Standard cotton (ST-CO) fabric by WFK of mass per unit area $170 \mathrm{~g} / \mathrm{m}^{2}$, canvas embroidery; the commercial cotton fabrics, white - optical brightened $(\mathrm{H}-\mathrm{W})$, and dark green (H-G), donated from company „DM TEKSTIL KROJAČKI OBRT“, Ozalj of mass per unit area $190 \mathrm{~g} / \mathrm{m}^{2}$; plain woven.

The standard cotton fabrics were cationized with 3-chloro-2-hydroxypropyl-trimethyl ammonium chloride (CHPTAC), and reactive polyammonium compounds Rewin
OS according to [3].

Cotton fabrics were treated with two QACs (tab.1), Ncetylpyridinium chloride (N-CPC) and cetylpyridinium bromide (CPB). 0.001 M QAC was adsorbed at $25^{\circ} \mathrm{C}, 30 \mathrm{~min}$, BR 1:20, on Heidolph Unimax 1010 orbital shaker. The adsorbed QAC amount was determined indirectly by potentiometric titration on automatic titration unit Titrino 736 GP (Metrohm) using ion-selective electrode (High Sense surfactant electrode, 6.0504.150, Metrohm) and $\mathrm{Ag} / \mathrm{AgCl}$ (Metrohm) as referent electrode. The $0.001 \mathrm{M}$ sodium lauryl sulphate (Sigma-Aldrich) was used as titrant/polyelectrolyte of opposite charge [5].

Table 1. Skeletal formula and molar mass of QACs

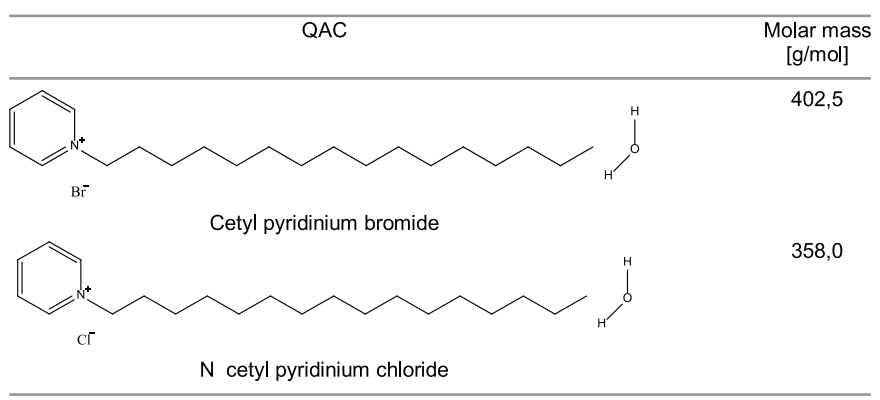

Labels and description of cotton fabrics are given in Table 2.

Table 2. Labels and description of cotton fabrics

\begin{tabular}{|c|c|}
\hline Label & Description of cotton fabrics \\
\hline ST-CO & Standard cotton fabric \\
\hline os & Cationized standard cotton fabric with Rewin OS \\
\hline CHPTAC & $\begin{array}{l}\text { Cationized standard cotton fabric with 3-chloro-2-hydroxypropyl-trimethyl ammonium } \\
\text { chloride (CHPTAC) }\end{array}$ \\
\hline $\mathrm{N}-\mathrm{CPC}$ & Standard cotton fabric treated with $\mathrm{N}$-cetylpyridinium chloride ( $\mathrm{N}-\mathrm{CPC}$ ) \\
\hline CPB & Standard cotton fabric treated with cetylpyridinium bromide (CPB) \\
\hline $\mathrm{H}-\mathrm{W}$ & Hospital white cotton fabric \\
\hline$H-G$ & Hospital green cotton fabric \\
\hline
\end{tabular}

Methods

The antimicrobial activity was determined according to AATCC TM 147-2016, Antibacterial Activity Assessment of Textile Materials: Parallel Streak Method. Activity was determined to Gram-positive bacteria Staphylococcus aureus ATCC 6538 (S. aures), Gram-negative bacteria Escherichia coli ATCC 8739 (E. coli), and microfungi - yeast Candida albicans ATCC 10231 (C. albicans).

On such hospital protective cotton fabrics several tests related to wetting and wicking were performed: AATCC TM 79-2014 Absorbency of Textiles, AATCC TM 197-2018 Vertical Wicking of Textiles; and AATCC TM 198-2018 Horizontal Wicking of Textiles; and AATCC TM 195-2017 Liquid Moisture Management Properties of Textile Fabrics on Moisture Management Tester (MMT M290 by SDL Atlas). Grading Table of all Indices according to AATCC TM 195 is shown in Table 3. 
Table 3. Grading Table of all Indices [26]

\begin{tabular}{lrccccc}
\hline Index & \multicolumn{5}{c}{ Grade } \\
& & 1 & 2 & 3 & 4 & 5 \\
\hline & Top & $\geq 120$ & $20-119$ & $5-19$ & $3-5$ & $<3$ \\
Bottom & $\geq 120$ & $20-119$ & $5-19$ & $3-5$ & $<3$ \\
& Top & $0-9$ & $10-29$ & $30-49$ & $50-100$ & $>100$ \\
& Bottom & $0-9$ & $10-29$ & $30-49$ & $50-100$ & $>100$ \\
& Top & $0-7$ & $8-12$ & $13-17$ & $18-22$ & $>22$ \\
& Bottom & $0-7$ & $8-12$ & $13-17$ & $18-22$ & $>22$ \\
& Top & $0.0-0.9$ & $1.0-1.9$ & $2.0-2.9$ & $3.0-4.0$ & $>4.0$ \\
& Bottom & $0.0-0.9$ & $1.0-1.9$ & $2.0-2.9$ & $3.0-4.0$ & $>4.0$ \\
\hline \\
$\begin{array}{l}\text { One-way Transport } \\
\text { Capability - (R) }\end{array}$ & $<-50$ & $-50-99$ & $100-199$ & $200-400$ & $>400$ \\
Overall Moisture & & & & & & \\
$\begin{array}{l}\text { Management Capability } \\
\text { (OMMC) }\end{array}$ & & & & & \\
\hline
\end{tabular}

The results obtained in this research are shown as Grading Summary Table e.g. Finger Print to summarize and illustrate the liquid moisture management properties: Wetting Time - WT T (top surface) and B (bottom surface), Absorption Rate - AR T and B; Maximum Wetted Radius - MWR T and B, Spreading Speed - SS T and B, Accumulative One-way Transport Capability (R), and Overall (liquid) Moisture Management Capability (OMMC) from the exact measured values. OMMC is an index to indicate the overall capability of the fabric to manage the transport of liquid moisture, which includes three aspects of performances: 1) Moisture absorption rate at bottom side, 2) One-way liquid transport capability, and 3) Moisture drying speed at bottom side, which is represented by accumulative spreading speed [27]. Based on the results the MMT classifies fabrics as shown in Table 4.

Table 4 . The major types of fabrics to describe fabric performance [27]:

\begin{tabular}{ll}
\hline Type of Fabric & Fabric performance \\
\hline Water Proof Fabric & - Very slow absorption \\
& - Slow spreading \\
& - No one-way transport, no penetration \\
Water Repellent Fabric & - No wetting \\
& - No absorption \\
& - No spreading \\
& - Poor one-way transport without external forces \\
Slow Absorbing and Slow Drying Fabric & - Slow absorption \\
& - Slow spreading \\
& - Poor one-way transport \\
Fast Absorbing and Slow Drying Fabric & - Medium to fast wetting \\
& - Medium to fast absorption \\
& - Small spreading area \\
& - Slow spreading \\
& - Poor one-way transport \\
Fast Absorbing and Quick Drying Fabric & - Medium to fast wetting \\
& - Medium to fast absorption \\
& - Large spreading area \\
Moisture Management Fabric & - Fast spreading \\
Water Penetration Fabric & - Poor one-way transport \\
& - Small spreading area \\
& - Excellent one-way transport \\
& - Medium to fast wetting \\
& - Medium to fast absorption \\
& - Large spread area at bottom surface \\
& - Fast spreading at bottom surface \\
& - Good to Excellent one-way transport \\
\hline & \\
\hline &
\end{tabular}

In addition to these tests, electrokinetic phenomena, Zeta potential $(Z P, \zeta)$ and isoelectric point (IEP) were determined by the streaming potential method on Electrokinetic Analyzer (Anton Paar) using stamp cell.

\section{Results and discussion}

In this paper, the moisture management, as one of the key performance criteria regarding the fabric comfort, was determined on cotton fabrics aimed to be used in the hospital environment. For that purpose, the commercial cotton fabrics to be used in hospital environment, as well as standard cotton fabric treated with different cationic agents for antimicrobial protection were researched.

Wicking and Capillarity

Several tests related to capillarity were performed. The results of AATCC TM 79-2014 Absorbency of Textiles, AATCC TM 197-2018 Vertical Wicking of Textiles; and AATCC TM 198-2018 Horizontal Wicking of Textiles are presented in Table 5. The results of AATCC TM 1952017 Liquid Moisture Management Properties of Textile Fabrics tested on Moisture Management Tester (MMT M290 by SDL Atlas are collected in Table 6, and Fingerprints are shown in Figures 1-7.

Table 5. Absorbency and Wicking of cotton fabrics

\begin{tabular}{lllr}
\hline Fabric & $\begin{array}{l}\text { AATCC TM 79 } \\
\text { Absorption of drop } \\
\text { t/s }\end{array}$ & $\begin{array}{l}\text { AATCC TM 197 } \\
\text { Length in 30 min } \\
\text { l/mm }\end{array}$ & \multicolumn{2}{l}{$\begin{array}{l}\text { AATCC TM } 198 \\
\text { Radius of 100 mm } \\
\text { t/s }\end{array}$} \\
\hline ST-CO & 0 & 55.0 & 59.3 \\
OS & 2.5 & 62.5 & 242.0 \\
CHPTAC & 0 & 71.0 & 143.3 \\
N-CPC & 0 & 56.5 & 146.5 \\
CPB & 0 & 54.0 & 96.5 \\
H-W & $>60$ & 2 & 102.7 \\
H-G & 2.5 & 61.0 & - \\
\hline
\end{tabular}

The quick Drop test AATCC TM 79-2014 Absorbency of Textiles indicate if the material is hydrophilic or hydrophobic. From the Table 5 it is evident that all tested cotton fabrics are hydrophilic except white cotton commercial fabric. The results of drop test indicate hydrophobic surface, probably treated with some water-repellent finishing. It was expected that standard cotton fabric has excellent hydrophilicity and high water absorbency after removal of all impurities of cotton in scouring and bleaching processes. The wetting time measured on MMT is the time period in which the top and bottom surfaces of the fabric just start to get wetted, and can be compared with the absorbency drop test [27]. Therefore, the results of wetting time for top and bottom show similar behavior as drop test. It is evident that the wetting time is less than $4 \mathrm{~s}$. White cotton fabric $(\mathrm{H}-\mathrm{W})$ show maximum wetting time of $120 \mathrm{~s}$, confirming hydrophobicity.

The results of AATCC TM 198-2018 Horizontal Wicking of Textiles presented in Table 5 represent the time for achieving radius of $100 \mathrm{~mm}$. It is noticeable that it takes $59.3 \mathrm{~s}$ to reach the proposed radius on a standard 
cotton fabric. Dyed and treated cotton fabrics take more time, suggesting that standard cotton fabric has best absorption. It is evident that on the cationized fabrics it take more time to reach the proposed radius. However, the MMT results for the maximum wetted ring radius of hydrophilic surfaces show similar results in 120 s. Cati- onized fabrics achieved radius of $20 \mathrm{~mm}$, while standard and dyed cotton fabric showed even higher radius (>23 $\mathrm{mm})$.

Table 6. Moisture management properties of cotton fabrics

\begin{tabular}{|c|c|c|c|c|c|c|c|c|c|c|}
\hline & $\begin{array}{l}\text { Wetting } \\
\text { Time } \\
\text { Top (s) }\end{array}$ & $\begin{array}{c}\text { Wetting } \\
\text { Time } \\
\text { Bottom } \\
\text { (s) }\end{array}$ & $\begin{array}{c}\text { Top } \\
\text { Absorption } \\
\text { Rate }(\% / s)\end{array}$ & $\begin{array}{c}\text { Bottom } \\
\text { Absorption } \\
\text { Rate }(\% / s)\end{array}$ & $\begin{array}{c}\text { Top } \\
\text { Max } \\
\text { Wetted } \\
\text { Radius } \\
(\mathrm{mm})\end{array}$ & $\begin{array}{c}\text { Bottom } \\
\text { Max } \\
\text { Wetted } \\
\text { Radius } \\
(\mathrm{mm})\end{array}$ & $\begin{array}{l}\text { Top } \\
\text { Spreading } \\
\text { Speed } \\
(\mathrm{mm} / \mathrm{s})\end{array}$ & $\begin{array}{l}\text { Bottom } \\
\text { Spreading } \\
\text { Speed } \\
(\mathrm{mm} / \mathrm{s})\end{array}$ & $\begin{array}{c}\text { Accumulative } \\
\text { One-way } \\
\text { transport } \\
\text { index (\%) }\end{array}$ & OMMC \\
\hline $\mathrm{ST}-\mathrm{CO}$ & 4.961 & 3.6193 & 19.7889 & 22.5173 & 23.3333 & 23.3333 & 2.8959 & 2.747 & 419.2673 & 0.6797 \\
\hline $\mathrm{cv}$ & 0.5738 & 0.1223 & 0.1402 & 0.4886 & 0.1237 & 0.1237 & 0.4537 & 0.2188 & 0.0534 & 0.1157 \\
\hline os & 3.3225 & 3.6735 & 71.9175 & 63.7538 & 20 & 20 & 3.6702 & 3.4978 & 25.7162 & 0.4416 \\
\hline $\mathrm{cv}$ & 0.0162 & 0.0128 & 0.0427 & 0.0186 & 0 & 0 & 0.0047 & 0.0064 & 0.3779 & 0.0256 \\
\hline CHPTAC & 3.1358 & 3.3700 & 69.6547 & 63.9705 & 20 & 20 & 3.7219 & 3.5693 & 13.623 & 0.4347 \\
\hline $\mathrm{cv}$ & 0.0386 & 0.0507 & 0.0153 & 0.0141 & 0 & 0 & 0.0207 & 0.022 & 0.6126 & 0.0327 \\
\hline $\mathrm{N}-\mathrm{CPC}$ & 3.4446 & 3.6318 & 73.3792 & 71.7086 & 22 & 23 & 3.6263 & 3.516 & -46.8781 & 0.3951 \\
\hline $\mathrm{cr}$ & 0.0524 & 0.0616 & 0.0491 & 0.0273 & 0.1245 & 0.1191 & 0.0762 & 0.0458 & 0.5837 & 0.081 \\
\hline CPB & 3.482 & 3.613 & 72.9964 & 66.8039 & 20 & 23 & 3.4304 & 3.4189 & -70.662 & 0.3653 \\
\hline $\mathrm{cv}$ & 0.0351 & 0.0349 & 0.0386 & 0.0502 & 0 & 0.1191 & 0.0463 & 0.0589 & 0.4619 & 0.0255 \\
\hline $\mathrm{H}-\mathrm{W}$ & 120 & 6.9452 & 0 & 60.5968 & 0 & 5 & 0 & 0.707 & 927.8558 & 0.6405 \\
\hline $\mathrm{cv}$ & 0 & 0.1084 & 0 & 0.0937 & 0 & 0 & 0 & 0.1001 & 0.0513 & 0.0246 \\
\hline $\mathrm{H}-\mathrm{G}$ & 4.2308 & 4.7174 & 32.9693 & 55.1767 & 27 & 27 & 3.4171 & 3.2665 & 121.8754 & 0.5053 \\
\hline $\mathrm{cv}$ & 0.2072 & 0.2153 & 0.293 & 0.1436 & 0.1014 & 0.1014 & 0.162 & 0.1545 & 0.7598 & 0.0924 \\
\hline
\end{tabular}

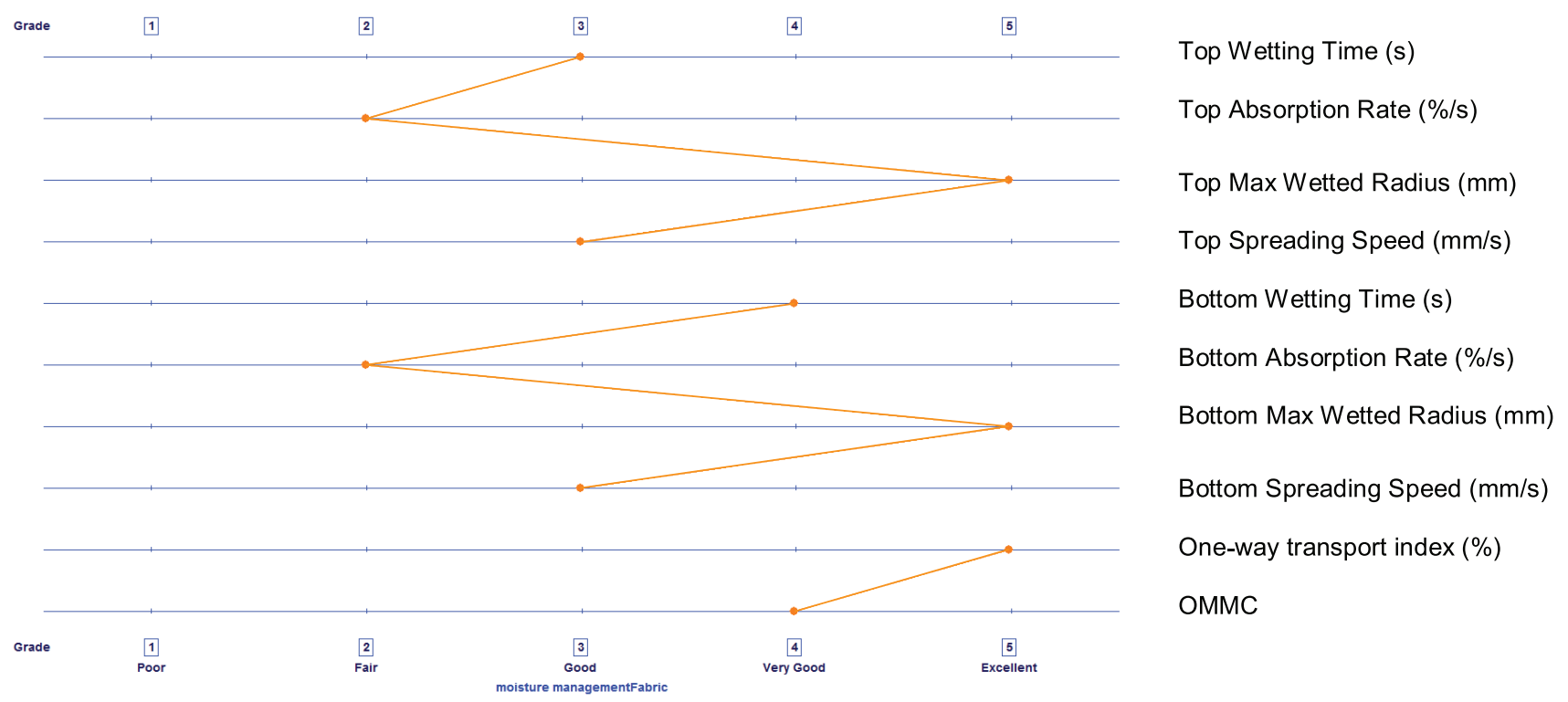

Figure 1. Fingerprint of standard cotton fabric (ST-CO) according to AATCC TM 195-2017 


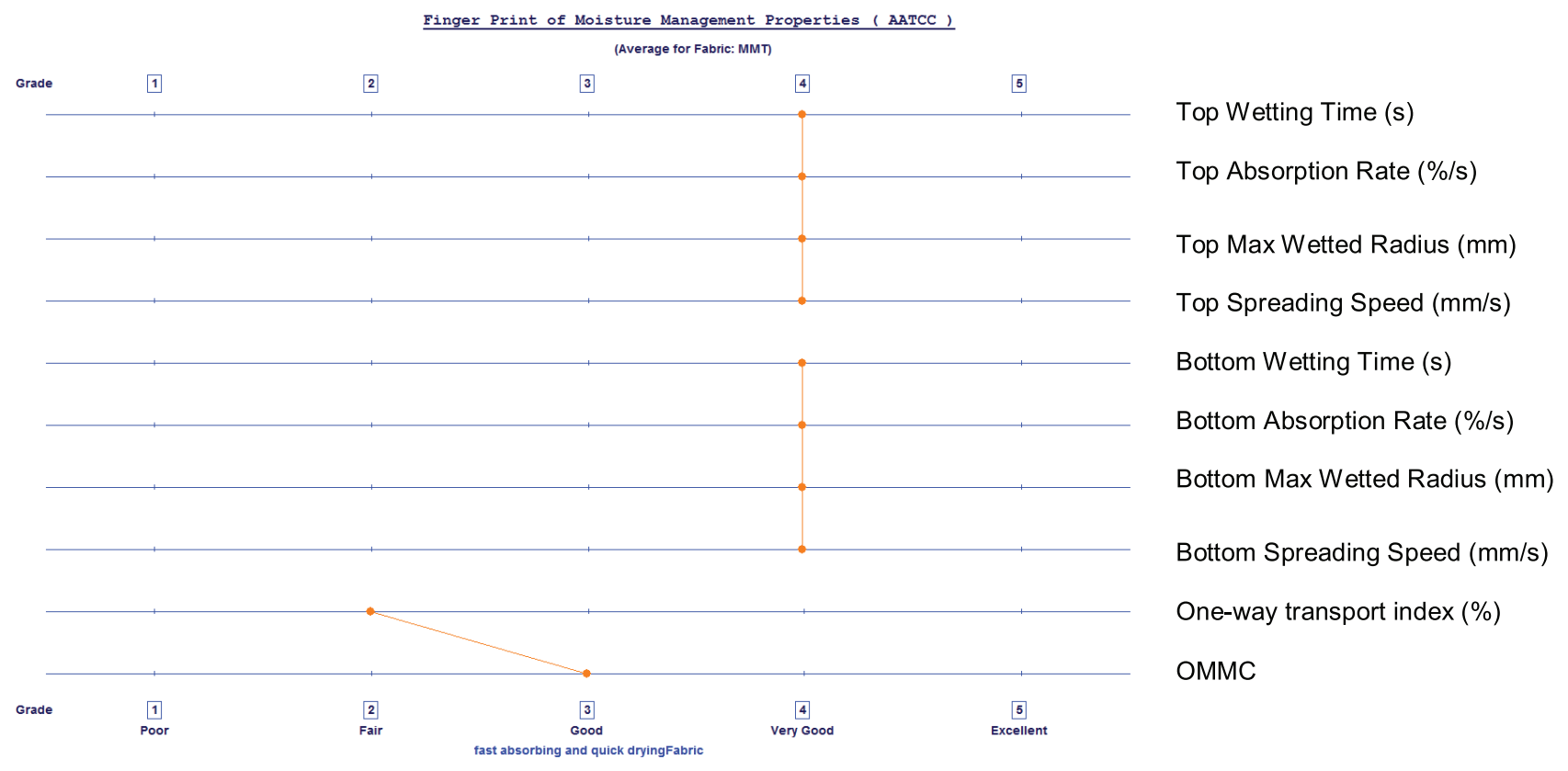

Figure 2. Fingerprint of standard cotton fabric cationized with Rewin OS (OS) according to AATCC TM 195-2017

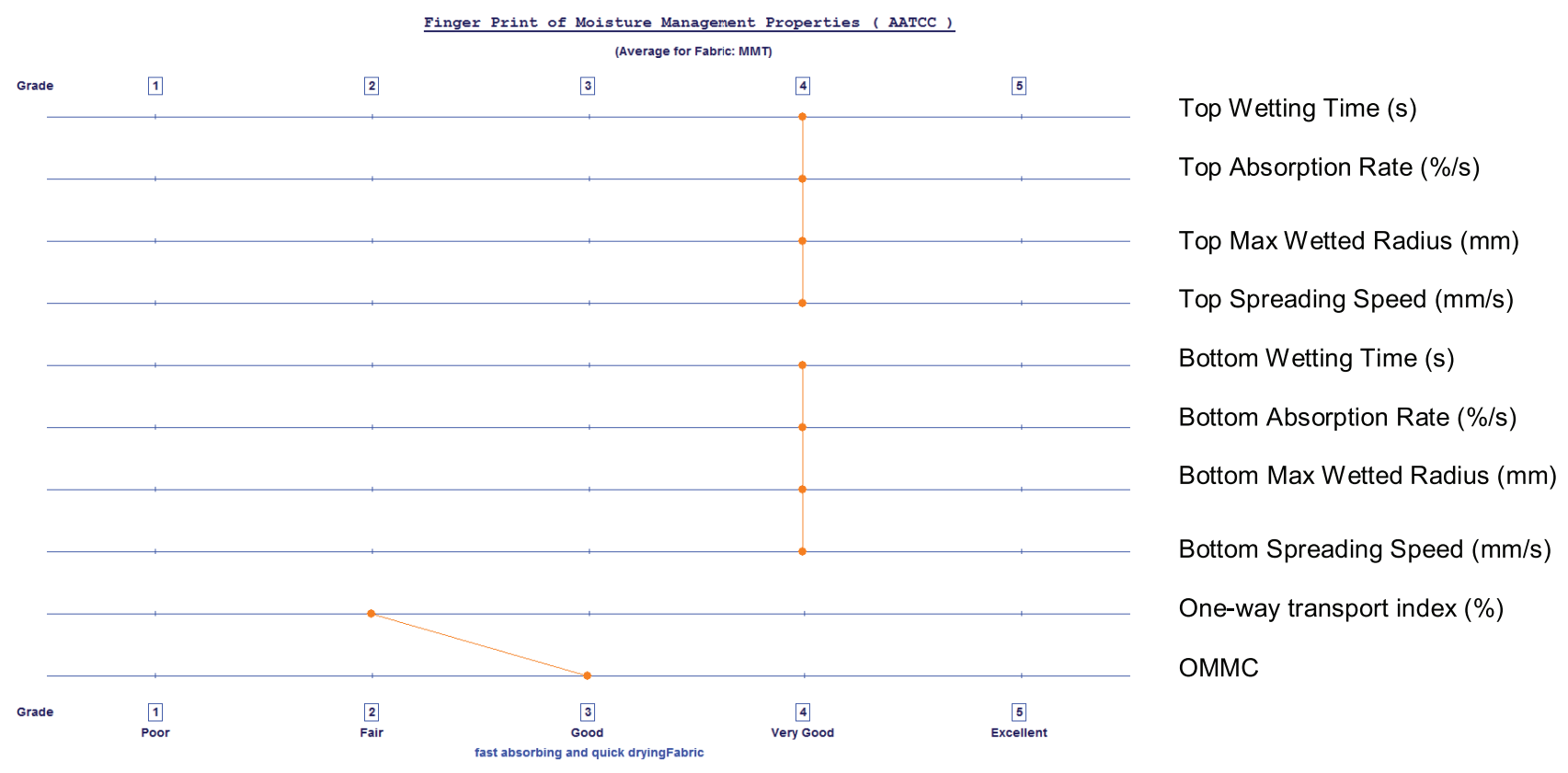

Figure 3. Fingerprint of standard cotton fabric cationized with CHPTAC according to AATCC TM 195-2017 
Finger Print of Moisture Management Properties (AATCC)

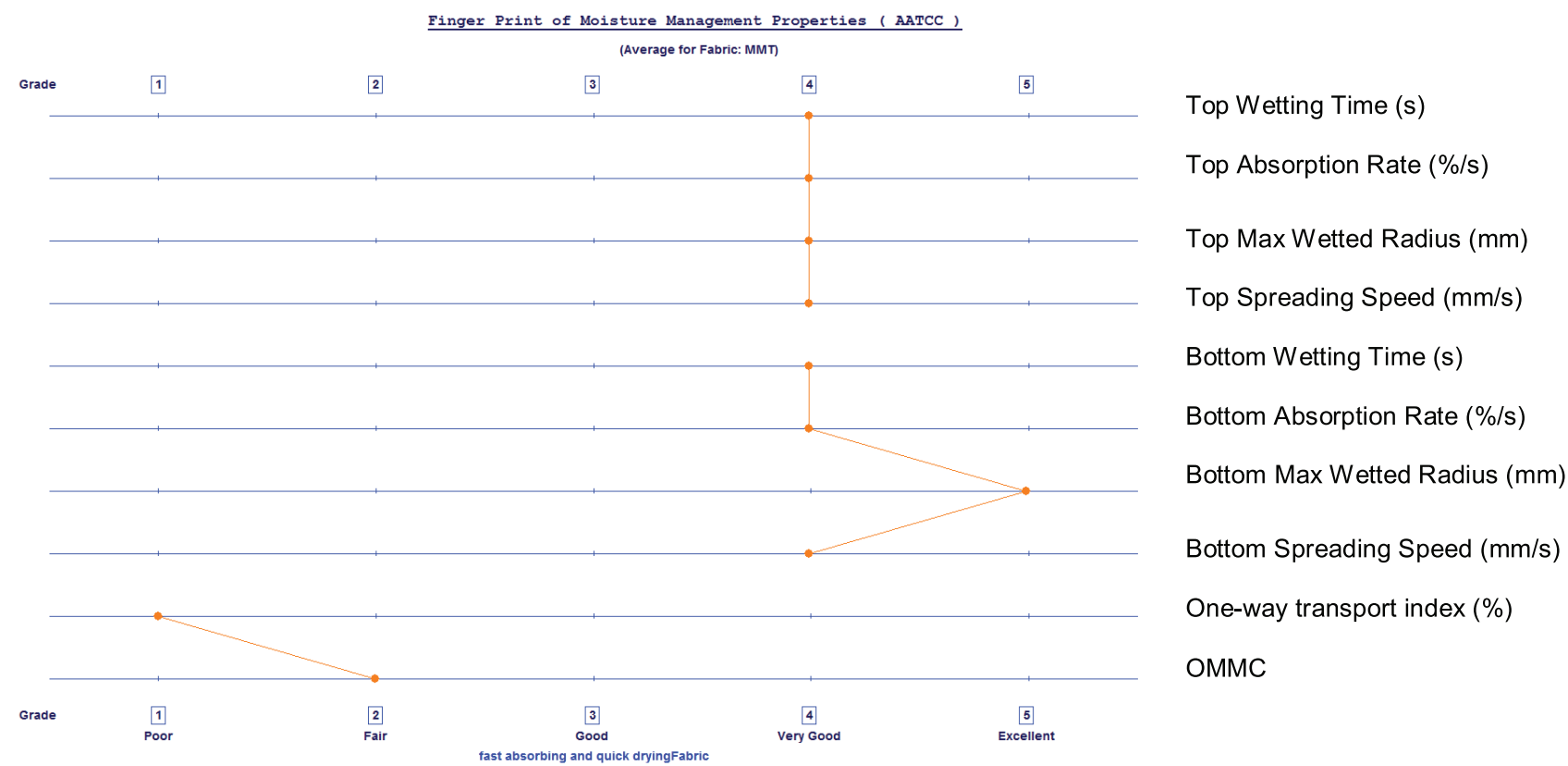

Figure 4. Fingerprint of standard cotton fabric treated with N-CPC according to AATCC TM 195-2017

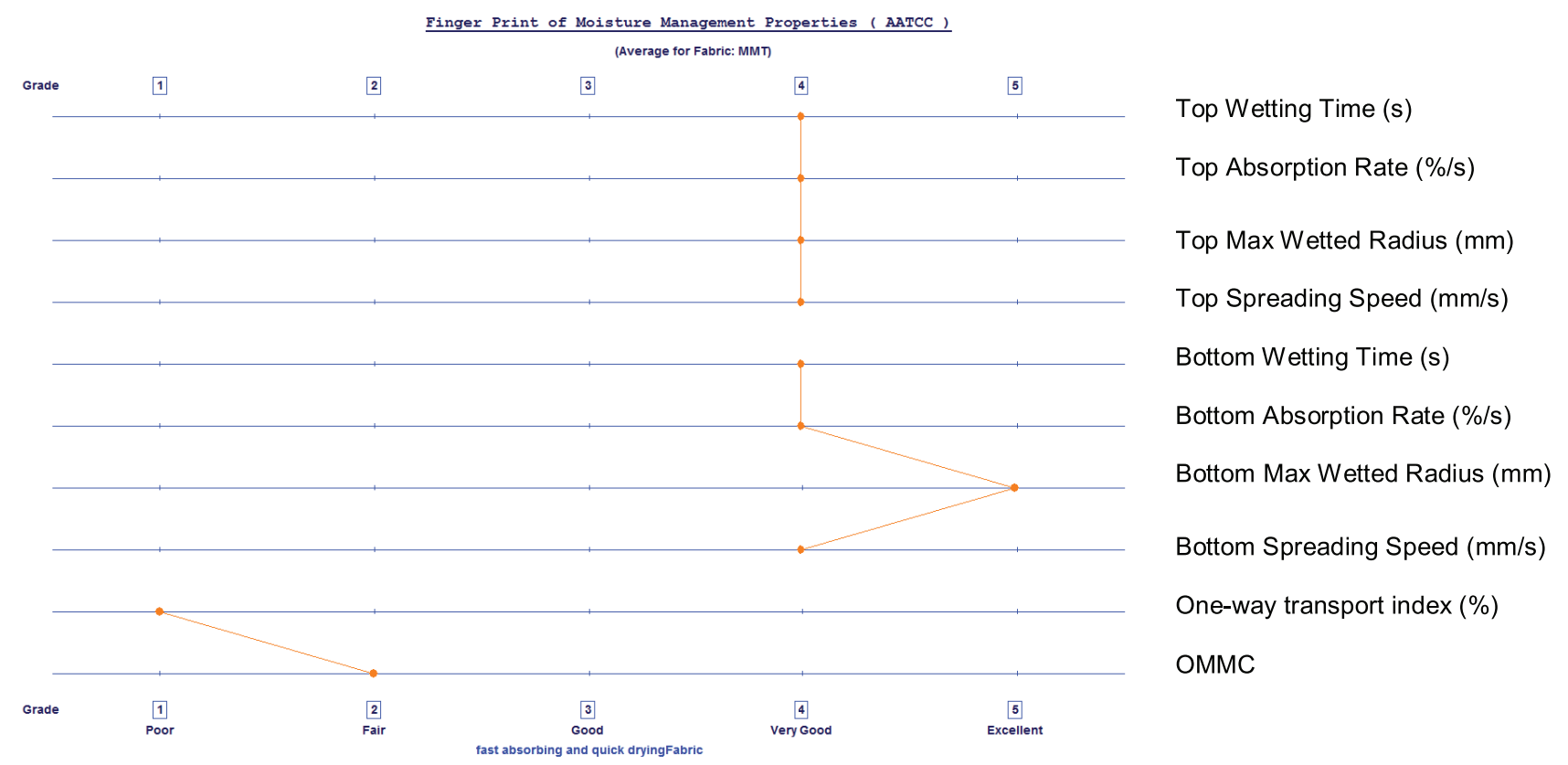

Figure 5. Fingerprint of standard cotton fabric treated with CPB according to AATCC TM 195-2017 


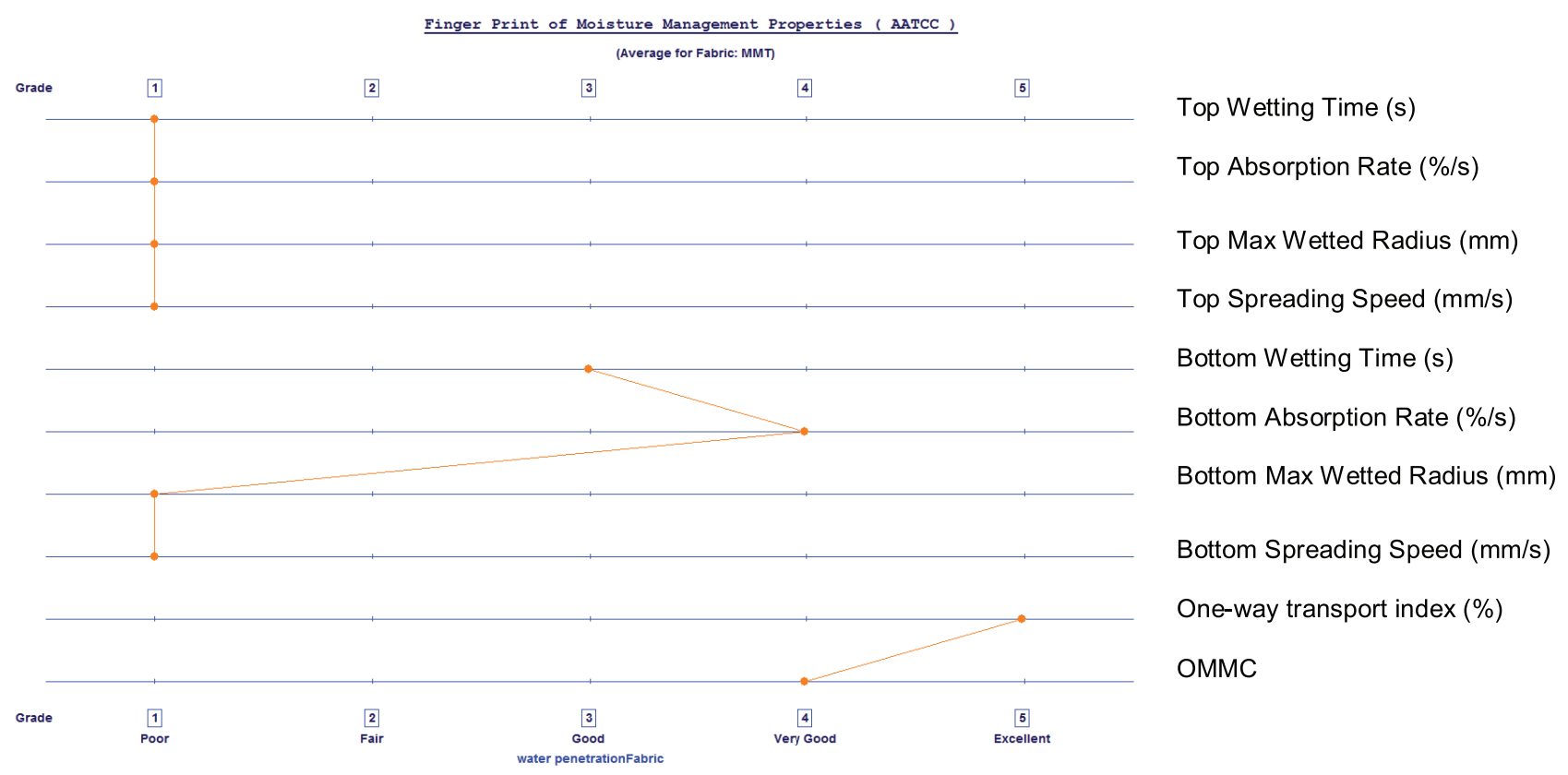

Figure 6. Fingerprint of white hospital cotton fabric (H-W) according to AATCC TM 195-2017

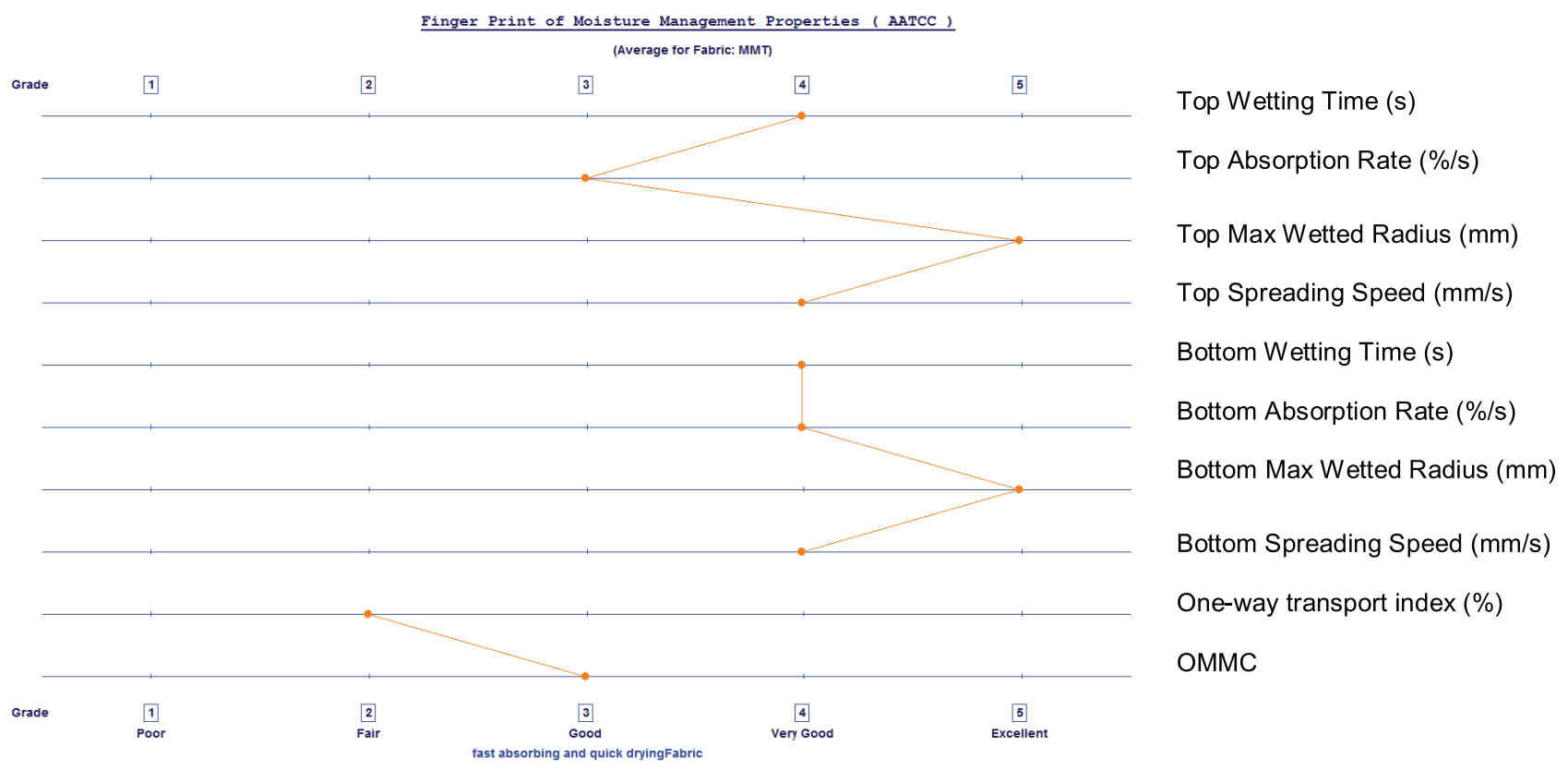

Figure 7. Fingerprint of green hospital cotton fabric (H-G) according to AATCC TM 195-2017

Absorption rate represents the average speed of liquid moisture absorption for the top and bottom surfaces of the specimen during the initial change of water content during a test. For standard cotton fabric it is around $20 \% / \mathrm{s}$. However, in treatment with cationic compounds, in cationization or with $\mathrm{QACs}$, it changes to $60-70 \% / \mathrm{s}$, indicating better capillarity. For that reason, the spread- ing speed, which represents the accumulated rate of surface wetting from the center of the sample where the test solution is dropped to the maximum wetted radius, is faster on cationic surfaces (from $2.8 \mathrm{~mm} / \mathrm{s}$ for ST-CO to $3.7 \mathrm{~mm} / \mathrm{s}$ for CHPTAC). The results of AATCC TM 1972018 Vertical Wicking of Textiles confirm these results. In 30 min waterfront moves due to capillarity of ST-CO fabric 
$55 \mathrm{~mm}$, whilst on CHPTAC fabric $71 \mathrm{~mm}$.

Cotton fiber has polar bonding sites for water molecules so it can absorb large quantity of liquid. Therefore, it has high absorption rate. Since it has a large spread area as well as fast spread, standard cotton fabric is characterized as moisture management fabric, having excellent one-way transport. All the results prove that this fabric has excellent hydrophilicity, and transports aqueous liquids such as perspiration or water.

The results of wetting time hospital white fabric $(\mathrm{H}-$ W) suggest hydrophobic treatment. Wetted radius of 5 $\mathrm{mm}$, slow spreading speed, small spreading area, and very good one-way transport suggests that this fabric is characterized as a water penetration fabric which is, on the one hand a good water repellant, and on the other it allows water vapor perspiration.

Accumulative one-way transport capability (OWTC) represents the difference between the area of the liquid moisture content curves of the top and bottom surfaces of a specimen with respect to time. For standard cotton fabric OWTC is $419,27 \%$ indicating that water content on top surface is much higher than on bottom suggesting high absorbency. Cationization and QAC treatment significantly lower OWTC. N-CPC and CPB treated fabrics show negative values indicating that water content top surface is lower than the one on fabric bottom surface. This suggests that the liquid introduced to the bottom surface is slowly transferred to the top surface [28].

Overall (liquid) moisture management capability (OMMC) is calculated by combining three measured attributes of performance: the liquid moisture absorption rate on the bottom surface, the one-way liquid transport capability, and the maximum liquid moisture spreading speed on the bottom surface. It represents an index of the overall capability of a fabric to transport liquid moisture. For cationized fabrics OMMC is good, and for fabrics with negative OWTC is fair; whilst for standard cotton fabric is very good even if dyed. Since all cationic fabrics have fast wetting, absorption and spreading, large spreading area, but poor one-way transport, they are characterized as Fast Absorbing and Quick Drying Fabric.

\section{Zeta potential}

Zeta potential and isoelectric point (IEP) were determined, and the results are presented in Figure 9 and Table 7 .

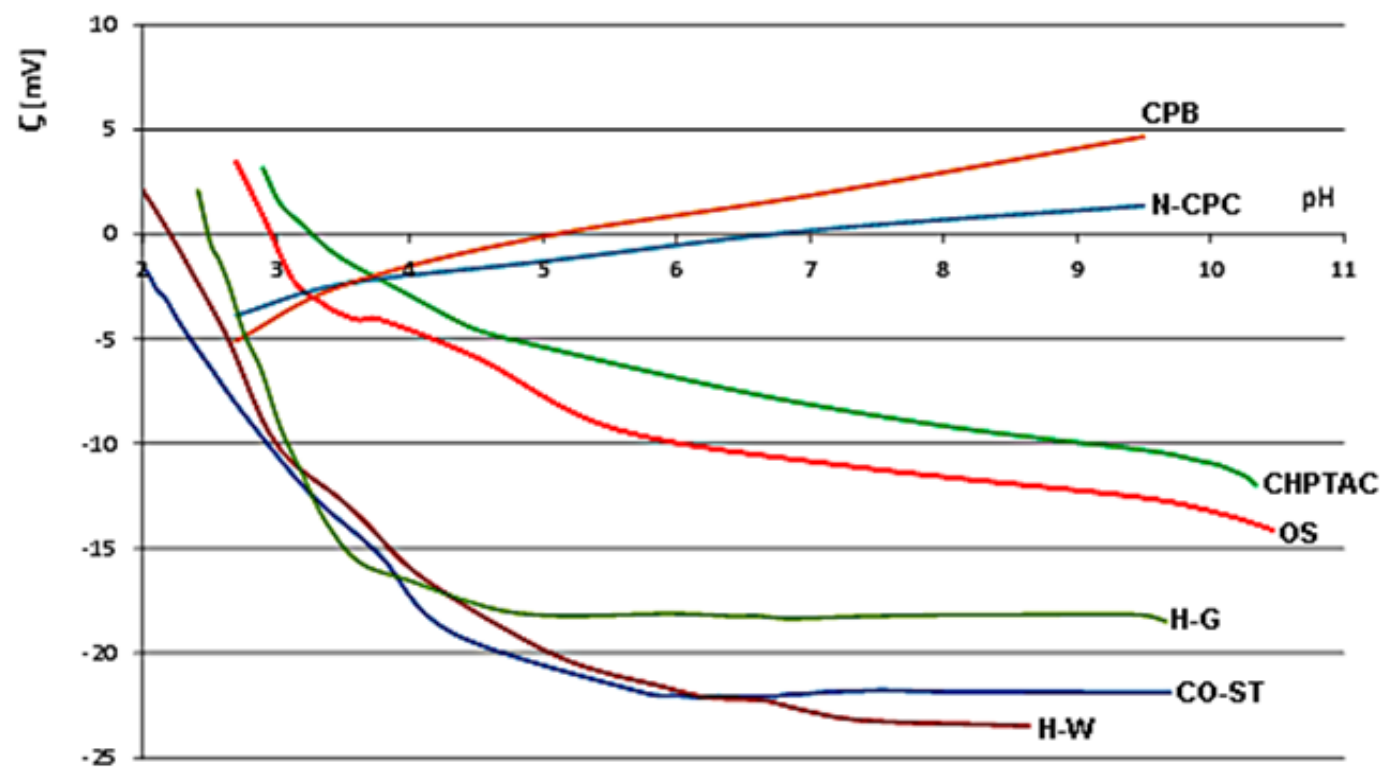

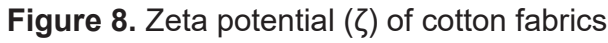

Standard cotton fabric is negatively charged due to presence of hydroxyl and carboxyl groups $(\zeta=-21.8 \mathrm{mV})$, as well as carboxylic groups reveled in scouring and bleaching processes. Water repellent treatment shifts the shear plane into the liquid phase lowering zeta potential of white hospital cotton fabric $(\zeta=-25.2 \mathrm{mV})$. Dyeing is blocking the surface groups resulting in higher zeta potential $(\zeta=-18.5 \mathrm{mV})$.
Table 7. Zeta potential at $\mathrm{pH} 9$ and 6.5 , and IEP of cotton fabrics

\begin{tabular}{llll}
\hline Fabric & $\begin{array}{c}\zeta[\mathrm{mV}] \\
\mathrm{pH} 9\end{array}$ & $\begin{array}{c}\zeta[\mathrm{mV}] \\
\mathrm{pH} 6.5\end{array}$ & \multicolumn{1}{c}{ IEP } \\
\hline ST-CO & -21.8 & -21.7 & $<2$ \\
OS & -12.2 & -10.3 & 2.95 \\
CHPTAC & -9.9 & -7.5 & 3.26 \\
N-CPC & 1.4 & 0 & 6.54 \\
CPB & 4.7 & 1.3 & 4.98 \\
H-W & -25.2 & -15.1 & 2.33 \\
H-G & -18.5 & -18.2 & 2.49 \\
\hline
\end{tabular}


The treatment of cellulose fibers with cationic compounds, surfactants or quaternary ammonium ions leads to significant modification of fiber surface resulting in the reversal of charge. In the case of cationized fabrics (OS and $\mathrm{CHPTAC}$ ), besides $-\mathrm{OH}$ and $-\mathrm{COOH}$ groups, $-\mathrm{NH}_{2}$ groups are present as well resulting in higher zeta poten-

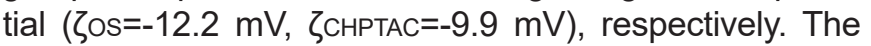
long-chain cationic compounds as QACs adsorb by primarily electrostatic forces, reversing the original negative charge of the cellulose $\left(\zeta_{\mathrm{N}} \mathrm{CPC}=1.4 \mathrm{mV}, \zeta_{\mathrm{CPB}}=4.7 \mathrm{mV}\right)$. This process occurs within the Stern layer at inner Helmholtz plane. Due to its long hydrophobic chain, the next phase of adsorption is tail-to-tail coupling, whereby the positively charged molecule heads are directed toward the bulk liquid; this positive charge is reflected as a more positive zeta potential as well. Unlike long-chain cationic compounds, the short-chain quaternary ammonium salts such as CHPTAC, strongly binds to the surface sites forming the covalent bonds.
Antimicrobial activity

For hospital textiles the antimicrobial activity is important as well as capillarity and moisture management. The antimicrobial activity was determined according to AATCC TM 147-2016 to Gram-positive bacteria Staphylococcus aureus, Gram-negative bacteria Escherichia coli, and microfungi Candida albicans. This test methods have the highest standards for antimicrobial activity on textiles. Results are presented in Table 8.

From the results in Table 8 it can be seen that cotton fabrics do not give any antimicrobial activity if not treated (standard cotton fabric, hospital white fabric for beddings and hospital green fabric for gowns and instrument covers). For usage in hospital it is important to do antimicrobial treatment.

The cationization of cotton leads to antimicrobial activity to $S$. aureus. However, it has no activity to $E$. coli and C. albicans. QACs, N-cetylpyridinium chloride (N-CPC) and cetylpyridinium bromide (CPB), application resulted in full antimicrobial activity to bacteria and microfungi.

Table 8. Antimicrobial activity of cotton fabrics to S. aureus, E. coli and C. albicans

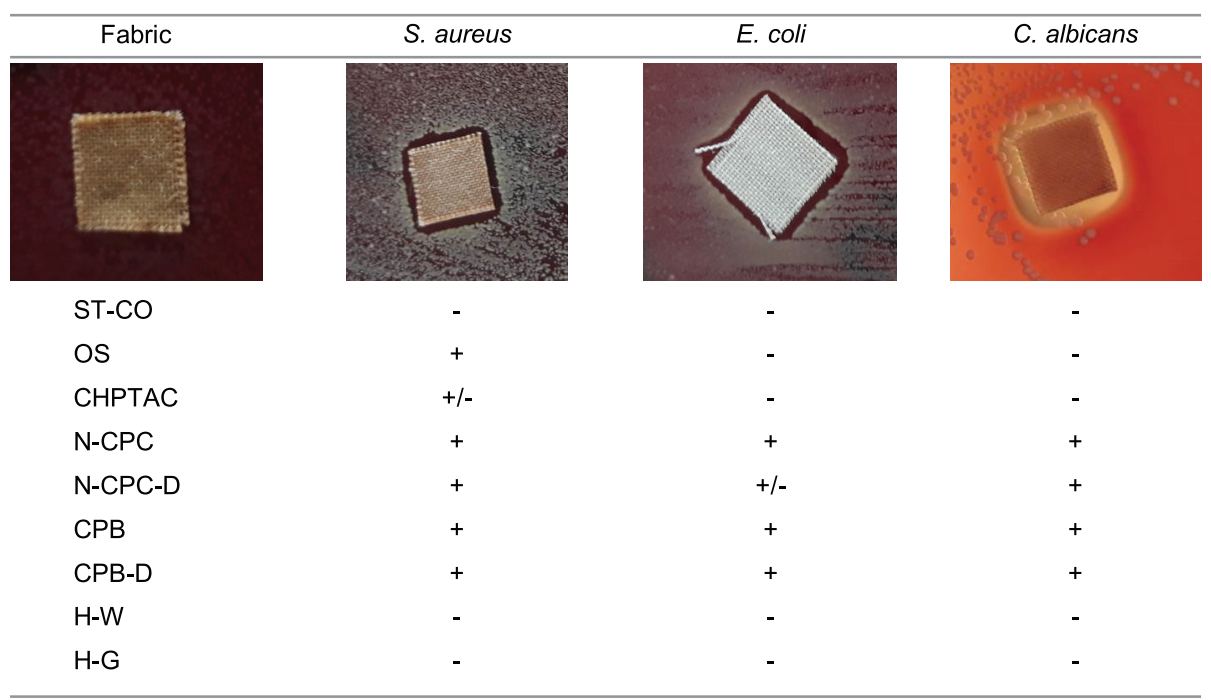

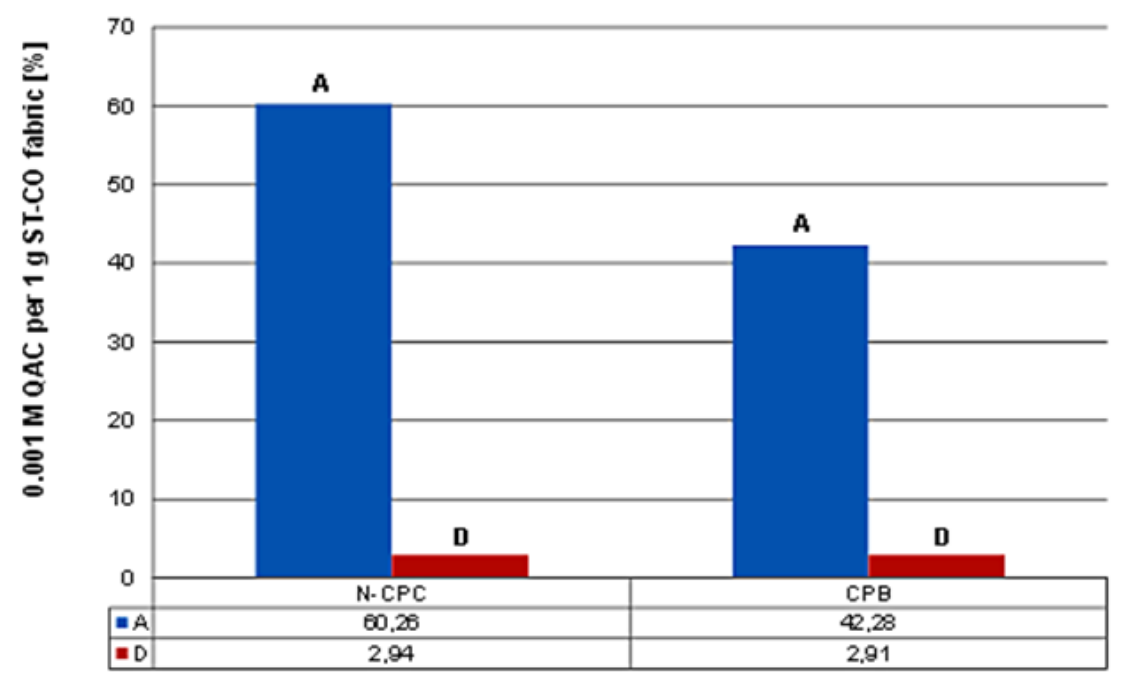

Figure 9. The adsorption (A) and desorption (D) of $0.001 \mathrm{M}$ QACs on standard cotton fabric 
The results showed that both QACs have high activity against all microorganisms tested. It is well known that both act as surfactants and antiseptics. However, it is usually desorbed from fabrics during washing. For that reason, the adsorption and desorption of N-CPC and CPB on standard cotton fabric were researched, as well its influence to fabric antimicrobial properties.

From the results of adsorption (A) and desorption (D) of $0.001 \mathrm{M}$ QACs on standard cotton fabric presented in Figure 9 it can be seen that 3\% of QACs is desorbed in water. Introduced in laundry process it can interact with anionic surfactant in detergent, leaving incrustation and result without antimicrobial activity.

Because of that, QAC treated fabrics were desorbed in water for $30 \mathrm{~min}$, and tested again. The results confirm excellent activity after washing as well, but the difference between QACs can be noticed. While the antimicrobial activity on Gram negative bacteria Escherichia coli disappears after washing due to desorption of N-CPC, for CPB activity is still present.

\section{Conclusion}

Standard cotton fabric has excellent hydrophility, fast absorption, fast spreading and large spread area at bottom surface and good one-way transport. It is characterized as Moisture management fabric. Hospital white fabric for beddings has water repellent treatment; however, it is breathing and can be characterized as water penetration fabric. Hospital green fabric for gowns and instrument covers, due to dyestuff blocking the active groups have smaller absorption, and can be characterized as Fast absorbing and quick drying fabric. Unfortunately, untreated cotton fabrics do not give any antimicrobial activity.

High number of $-\mathrm{OH}$ and $-\mathrm{COOH}$ groups gives cotton fabrics negative zeta potential. By cationization, the surface charge has changed; $-\mathrm{NH}_{2}$ groups result in more positive charge, as well as antimicrobial activity. Both cationized cotton fabrics are characterized by MMT as Fast absorbing and quick drying fabric as they have fast wetting, absorption and spreading properties, a large surface area, but poor one-way transport.

In QAC treated fabrics this effect is enhanced. However, these fabrics have excellent antimicrobial activity even after desorption. Based on the results of wetting and wicking, zeta potential and antimicrobial activity, CPB treatment is proposed for the processing of cotton fabrics.

\section{Acknowledgment}

This work has been supported in part by Croatian Science Foundation under the project UIP-2017-05-8780 HPROTEX.

\section{References}

[1] S. Bischof Vukušić, S. Flinčec Grgac, D. Katović, Antimikrobna modifikacija tekstilija i problematika metoda ispitivanja, Tekstil, 56 (1) (2007) 36-49.

[2] A. Budimir, S. Bischof Vukušić, S. Flinčec Grgac, Study of antimicrobial properties of cotton medical textiles treated with citric acid and dried/cured by microwaves, Cellulose, 19(1) (2011) 289-296.

[3] G. McDonnell, A. D. Russell, Antiseptics and Disinfectants: Activity, Action, and Resistance, Clin. Microbiol. Rev. 12 (1999) 147-179.

[4] Y. Gao, R. Cranston, Recent Advances in Antimicrobial Treatments of Textiles, Textile Research Journal 78(1) (2008) 60-72.

[5] A. Crutzen, Fabric softeners, in Liquid Detergents, K.Y. Lai Ed., 2nd edition, CRC Press, SAD, 2006.

[6] K.-P. Tang, C.-W. Kan, J. Fan, Evaluation of water absorption and transport property of fabrics, Textile Progress, 46(1) (2014) 1-132.

[7] B. Das, A. Das, V. K. Kothari, R. Fanguiero, M. de Araújo, Moisture Transmission through Textiles, Part I: Processes involved in moisture transmission, AUTEX Research Journal 7(2) (2007) 100-110.

[8] B. Das, A. Das, V. K. Kothari, R. Fanguiero, M. de Araújo, Moisture Transmission through Textiles, Part II: Evaluation Methods and Mathematical Modelling, AUTEX Research Journal 7(3) (2007) 194-216.

[9] B. Das, A. Das, V. K. Kothari, R. Fanguiero, M. de Araújo, Moisture Flow through Blended Fabrics - Effect of Hydrophilicity, Journal of Engineered Fibers and Fabrics, 4(4) (2009) 20-28.

[10] Y. Jhanji, D. Gupta, V. K. Kothari: Moisture management properties of plated knit structures with varying fiber types, The Journal of The Textile Institute 106(6) (2015) 663-673.

[11] R.H. McQueen, J. C. Batcheller, T. Mah, P. M. Hooper, Development of a protocol to assess fabric suitability for testing liquid moisture transport properties, The Journal of The Textile Institute, 104(8) (2013) 900-905.

[12] E. Kissa, Wetting and Wicking, Textile Research Journal 66 (1996) 10, 660-668

[13] A. M. Grancarić, E. Chibowski, A. Tarbuk, Slobodna površinska energija tekstila, Tekstil 57(1-2) (2008) 29-39.

[14] T. Ramachandran, N. Kesavaraja, A Study of Influencing Factors for Wetting and Wicking Behaviour, IE (I) JournalTX, 84 (2004) 37-41

[15] A. Tarbuk, A. M. Grancarić, M. Leskovac, Novel cotton cellulose by cationization during mercerisation - Part 2: Interface phenomena, Cellulose 21(3) (2014) 2089-2099.

[16] A. M. Grancarić, A. Tarbuk, T. Pušić, Electrokinetic Properties of Textile Fabrics, Coloration Technology 121(4) (2005) 221-227.

[17] T. Pušić, A. M. Grancarić, A. Tarbuk, O. Šauperl , I. Soljačić, Adsorption and Desorption of Ionic Surfactants, Tenside, surfactants, detergents, 47 (2010) 173-178.

[18] A. Tarbuk, A. M. Grancarić, M. Leskovac, Novel cotton cellulose by cationisation during the mercerisation process - Part 1: Chemical and morphological changes, Cellulose 21(3) (2014) 2167-2179.

[19] L. Černe, B. Simončič, Influence of repellent finishing on the surface free energy of cellulosic textile substrates, Textile Research Journal, 74(5) (2004) 426-432.

[20] K. Stana-Kleinschek, V. Ribitsch, Electrokinetic properties of Processed Cellulose Fibers, Colloids and Surfaces, A: 
Physicochemical and Engineering Aspects, 140(1-3) (1998) 127-138.

[21] K. Stana-Kleinschek, S. Strand, V. Ribitsch, Surface Characterization and Adsorption Abilities of Cellulose Fibers, Polymer Engineering and Science 39 (8) (1999) 1412-1424.

[22] T. Pušić, A. M. Grancarć, I. Soljačić, V. Ribitsch, The Effect of Mercerization on the Electrokinetic Potential of Cotton, Journal of the Society of Dyers and Colourists, 115 (4) (1999) 121-124.

[23] T. Luxbacher, Electrokinetic properties of natural fibres, In Handbook of Natural Fibres: Processing and Applications, Volume 2 in Woodhead Publishing Series in Textiles. R. M. Kozłowski Ed., Elsevier, 2012, p. 185-216.

[24] E. Chibowski, F. Gonzalez-Caballero, Theory and Practice of Thin-Layer Wicking, Langmuir 9(1) (1993) 330-340.
[25] A. M. Grancarić, E. Chibowski, T. Pušić, I. Soljačić Lj. Plantić, Surface Free Energy of Conventional and Enzymatically Scoured Cotton Fabrics. Book of proceedings of the $1^{\text {st }}$ ITC\&DC, Faculty of Textile Technology, University of Zagreb, Zagreb, (2002) pp. 267273.

[26] AATCC 195-2017: Liquid Moisture Management Properties of Textile Fabrics, American Association of Textile Chemists and Colorists, (2018)

[27] M290 Moisture Management Tester, Instruction Manual, Rev. 1.4 (06/18) www.sdlatlas.com

[28] R. Nemcokova, V. Glombikova, P. Komarkova, Study on Liquid Moisture Transport of Knitted Fabrics by Means of MMT, AUTEX Research Journal 15(4) (2015) 233-242.

Izvod

\section{KVAŠENJE I NAMAKANJE BOLNIČKOG ZAŠTITNOG TEKSTILA}

Anita Tarbuk, Sandra Flinčec Grgac, Tihana Dekanić

Univerzitet u Zagrebu, Tekstilno-tehnološki fakultet, Zavod za tekstilnu hemiju i ekologiju, Zagreb, Hrvatska

Upravljanje vlagom, kao jednim od ključnih kriterijuma performansi u pogledu komfora tkanine, konkretno na pamučnim tkaninama namenjenim za upotrebu u bolničkom okruženju, istraživano je u ovom radu. U tu svrhu su upotrebljene komercijalne pamučne tkanine za operativnu odeću i bolničku posteljinu, kao i standardna pamučna tkanina tretirana različitim katjonskim agensima za antimikrobnu zaštitu. Antimikrobna svojstva standardnih pamučnih tkanina postignuta su katjonizacijom 3-hloro-2-hidroksipropil-trimetil-amonijum-hloridom (CHPTAC) i reaktivnim poliamonijum jedinjenjima Rewin OS; kao i tretiranjem sa kvaternernim agensima amonijuma dugog lanca, N-cetilpiridinijum hloridom (N-CPC) i cetilpiridinijum bromidom (CPB), koji deluju kao surfaktanti i antiseptici. Standardna pamučna tkanina ima odličnu hidrofilnost, brzo upijanje i širenje, veliku površinu širenja i dobar prenos u jednom smeru. Karakteriše se kao "tkanina za upravljanje vlagom". Bolnička bela tkanina za posteljinu ima vodoodbojnu obradu; mada diše i može se okarakterisati kao "tkanina za prodiranje vode". Bolnička tkanina u zelenoj boji za odeću i prekrivače za instrumente sa smanjenom apsorpcijom zbog blokiranja aktivnih grupa bojom, može se okarakterisati kao "tkanina koja brzo upija i brzo se suši". Pamučne tkanine imaju negativan zeta potencijal. Katjonizacijom se površinsko nalelektrisanje menja, kao i antimikrobna aktivnost. Obe katjonizovane pamučne tkanine okarakterisane su kao "tkanina koja brzo upija i brzo se suši", jer imaju brzo vlaženje, brzo upijanje, veliku površinu i brzo širenja tečnosti, ali loš prenos u jednom smeru. Za tkanine tretirane surfaktantima ovaj efekat je pojačan. Međutim, ove tkanine imaju odlično antimikrobno delovanje čak i nakon desorpcije. Na osnovu rezultata kvašenja, penetracije tečnosti, zeta potencijala i antimikrobne aktivnosti predlaže se CPB za obradu pamučnih tkanina.
(ORIGINALNI NAUČNI RAD) UDK 677.017:615.478.2

Ključne reči: bolnički tekstil, katjonizacija, antimikrobna asvojstva, upravljanje vlagom, zeta potencijal, kvašenje i penetracija. 